\title{
PENINGKATAN KETERAMPILAN MENYIMAK CERITA DRAMA DENGAN \\ PENERAPAN PEMBELAJARAN AKTIF INOVATIF KREATIF EFEKTIF MENYENANGKAN (PAIKEM) PADA SISWA KELAS VIII-A SMPN 2 SENTAJO RAYA
}

\begin{tabular}{|c|c|}
\hline \multicolumn{2}{|c|}{$\begin{array}{c}\text { Oleh } \\
\text { Agus Riyanto } \\
\text { SMP Negeri 2 Sentajo Raya } \\
\text { Email: agusriyanto9330@gmail.com }\end{array}$} \\
\hline Article History & Abstract \\
\hline Received : January 2020 & This research was motivated by students of class VIII-A \\
\hline $\begin{array}{cl}\text { Accepted : February } \\
\\
2020\end{array}$ & $\begin{array}{l}\text { students' skills in listening to drama stories by applying } \\
\text { PAIKEM. The method used in this study is a qualitative }\end{array}$ \\
\hline Published : March 2020 & $\begin{array}{l}\text { and quantitative description through classroom action } \\
\text { research conducted in two action cycles. Each cycle } \\
\text { consists of two meetings, in each meeting consisting of } \\
\text { four meetings, namely planning, implementation, }\end{array}$ \\
\hline Keywords & $\begin{array}{l}\text { monitoring, and reflection. The results showed an } \\
\text { increase in the competency of listening to students }\end{array}$ \\
\hline $\begin{array}{l}\text { Keterampilan menyimak, } \\
\text { cerita drama, PAIKEM }\end{array}$ & $\begin{array}{l}\text { through the application of PAIKEM to class VIII-A } \\
\text { students of SMPN } 2 \text { Sentajo Raya. This is evidenced by } \\
\text { agreeing to the value of learning outcomes which shows } \\
24 \text { students who took the first class test totaling } 9 \text { people } \\
\text { have not yet reached the KKM score, } 15 \text { students } \\
\text { achieving the KKM score with a percentage of } 62.50 \% \\
\text { and with an average learning result of } 65.75 \text {. While in } \\
\text { the second cycle, increasing the number of students who } \\
\text { received the KKM value by } 22 \text { people with a percentage } \\
\text { of } 91.66 \% \text { with an average value of } 75.54 \text {. }\end{array}$ \\
\hline
\end{tabular}

\begin{abstract}
Abstrak
relitian ini dilatarbelakangi oleh rendahnya keterampilan menyimak siswa kelas VIII-A SMPN 2 Sentajo Raya. Penelitian ini bertujuan untuk meningkatkan keterampilan siswa dalam menyimak cerita drama dengan penerapan PAIKEM. Metode yang digunakan
\end{abstract}


dalam penelitian ini adalah deskripsi kualitatif dan kuantitatif melalui penelitian tindakan kelas (classroom action research) yang dilakukan dalam dua siklus tindakan. Masing-masing siklus terdiri dari dua pertemuan, dalam setiap pertemuan terdiri dari empat tahapan, yaitu perencanaan, pelaksanaan, pengamatan, dan refleksi. Hasil penelitian menunjukkan adanya peningkatan keterampilan menyimak siswa melalui penerapan PAIKEM pada siswa kelas VIII-A SMPN 2 Sentajo Raya. Hal ini dibuktikan dengan perolehan nilai hasil belajar yang menunjukkan 24 siswa yang mengikuti tes siklus I terdapat 9 orang siswa belum mencapai nilai KKM, 15 siswa mencapai nilai KKM dengan persentase $62,50 \%$ dan dengan rata-rata hasil belajar sebesar 65,75. Sedangkan pada siklus II mengalami peningkatan yang menunjukkan siswa telah mencapai nilai KKM sebanyak 22 orang dengan persentase $91,66 \%$ dengan dengan nilai rata-rata 75,54. 


\section{A. Pendahuluan}

Pendidik harus mampu merencanakan dan mengatur kegiatan belajar siswa melalui model-model pembelajaran. Dalam model pembelajaran, guru `juga perlu menentukan strategi pengajaran yang tepat dalam pelaksanaanya, sehingga dalam pelaksanaan pembelajaran guru berperan penting dalam pemilihan strategi/pendekatan dan model pembelajaran yang berdasarkan pada tujuan dan menentukan keberhasilan belajar siswa (Fatmah \& Jumadi, 2016). Hakikat Belajar menurut (Slameto, 1991) adalah "Suatu proses perubahan yaitu perubahan tingkah laku sebagai hasil dari interaksi dengan lingkungannya dalam memenuhi kebutuhan hidupnya atau belajar ialah suatu proses usaha yang dilakukan sesorang untuk memperoleh suatu perubahan tingkah laku yang baru secara keseluruhan, sebagai hasil pengalamannya sendiri dalam interaksi dengan lingkungannya.

Hasil belajar kemudian akan lebih melekat, dan tentu saja, dalam proses seperti peserta didik didorong dan dikondisikan untuk lebih kreatif (Hartono,
2012). Melalui proses dan hasil belajar, sistem pembelajaran masa lalu dianggap tidak mampu lagi menopang tercapainya tujuan pendidikan secara menyeluruh. Oleh karena itu, upaya melakukan inovasi bidang pembelajaran selalu dikembangkan (Siregar, Pariang Sonang \& Wardani Lia, 2017). Inovasi pembelajaran yang menarik tidak hanya memberikan ceramah. Namun, ada metode lain dalam menyampaikan materi kepada peserta didik. Pengajaran di masa lampau guru berdiri di depan kelas berjam-jam menyampaikan materi dan peserta didik hanya disuruh mendengarkan dan mencatat yang disampaikan oleh guru. Hal tersebut tentu akan menimbulkan rasa bosan dalam diri peserta didik, sehingga banyak peserta didik yang tidak mendengarkan dan justru melakukan kegiatan lain seperti mengobrol dengan teman sebangku pada saat pelajaran bahasa Indonesia.

Ruang lingkup mata pelajaran bahasa Indonesia mencakup komponen kemampuan berbahasa dan kemampuan bersastra yang meliputi aspek-aspek sebagai berikut: (1) mendengarkan; (2) berbicara; (3) membaca; (4) menulis (Antarika, 2016). 
Kurikulum K13 mencantumkan dilakukan pada kelas VIII-A SMPN 2 kompetensi dasar Menginterprestasi drama Sentajo Raya dengan jumlah siswa 24 (tradisional dan modern) yang dibaca dan ditonton/didengar pada setiap satuan pendidikan pada kelas VIII-A. Realitanya, kegiatan menginterprestasi drama (tradisional dan modern) yang dibaca dan ditonton/didengar dalam pembelajaran bahasa Indonesia kurang diminati oleh siswa disebabkan ketertarikan siswa dalam mengapresiasikan sastra sangatlah kurang.

Pembelajaran dalam menginterprestasi drama (tradisional dan modern) yang dibaca dan ditonton/ didengar pada siswa kelas VIII-A SMP Negeri 2 Sentajo Raya mengalami hambatan yang disebabkan oleh beberapa faktor. Faktor tersebut antara lain: pembelajaran ilustrasi yang belum optimal, strategi pembelajaran yang kurang tepat, pengelolaan kelas yang belum optimal, perilaku siswa yang malas mengerjakan, dan kurangnya media.

Peneliti melakukan pengamatan di kelas VIII-A SMPN 2 sebanyak 2 kali yaitu pada hari Jumat tanggal 05 April 2019 dan 08 April 2019, untuk mengetahui kegiatan belajar mengajar di kelas. Dari hasil observasi awal yang

\section{B. Metode Penelitian}

Jenis penelitian ini adalah Penelitian Tindakan Kelas (PTK). Metode penelitian ini adalah metode kualitatif dan kuantitatif. Desain penelitiannya menggunakan model Spiral Kemmis dan 
MC Taggart yang terdiri dari empat komponen yaitu perencanaan, (planning), tindakan (action), pengamatan, (observer), dan refleksi (reflection). Secara garis besar pelaksanaan PTK dilakukan dalam empat tahapan, yaitu: perencanaan, pelaksanaan, pengamatan dan refleksi (Elvina, 2016).

\section{Hasil Penelitian dan Pembahasan}

\section{Hasil Penelitian}

Tabel 1. Analisis Peningkatan Aktivitas Siswa Siklus I ke Siklus II

\begin{tabular}{|c|c|c|c|c|}
\hline & \multicolumn{3}{|c|}{$\begin{array}{c}\text { Persentase Jumlah Skor } \\
\text { yang Dicapai }\end{array}$} & \multirow{2}{*}{$\begin{array}{c}\text { Persen } \\
(\%) \\
\text { Peningk } \\
\text { atan }\end{array}$} \\
\hline & Siklus I & $\begin{array}{l}\text { Siklus } \\
\text { II }\end{array}$ & $\begin{array}{c}\text { Selisi } \\
\mathrm{h} \\
\text { Skor }\end{array}$ & \\
\hline Siswa & $79,48 \%$ & $91,15 \%$ & 112 & $11,67 \%$ \\
\hline
\end{tabular}

Berdasarkan Tabel di atas, tentang peningkatan proses aktivitas siswa dalam pembelajaran menyimak cerita drama. Dapat diketahui bahwa terjadi peningkatan dari siklus I ke siklus II. Adapun presentase jumlah skor yang dicapai pada siklus I sebesar 79,48\% meningkat menjadi $91,15 \%$ pada silus II. Selisih skor 112 dengan presentase peningkatan sebesar $11,67 \%$.
Peningkatan

keterampilan

menyimak cerita drama siswa dilihat dari nilai hasil tes yang telah dilakaukan pada pra siklus, siklus I, dan siklus II. Berdasarkan nilai hasil tersebut, maka terdapat perbandingan antara nilai pra siklus, siklus I, dan siklus II. Hal itu terlihat dari tabel berikut:

Tabel 2. Analisis Perbandingan Peningkatan Nilai Hasil Tes Kemampuan menyimak Cerita Drama

\begin{tabular}{|l|l|l|l|l|l|}
\hline Hasil Tes & $\begin{array}{l}\text { Banyak } \\
\text { Siswa }\end{array}$ & T & $\%$ & TT & $\%$ \\
\hline Pra Siklus & 24 & 9 & $37,5 \%$ & 15 & $62,5 \%$ \\
\hline Siklus I & 24 & 15 & $62,5 \%$ & 9 & $37,5 \%$ \\
\hline Siklus II & 24 & 22 & $91,6 \%$ & 2 & $8,3 \%$ \\
\hline
\end{tabular}

Tabel di atas, memperlihatkan terjadinya peningkatan ketuntasan kemampuan menyimak cerita drama siswa siswa. Siswa yang tuntas pada pra siklus hanya 9 orang dengan persentase $37.5 \%$, siklus I naik menjadi 15 dengan persentase $62,5 \%$, dan siklus II meningkat menjadi 22 siswa dengan mencapai persentase 91,67\%. Hal ini menunjukan bahwa dengan penerapan PAIKEM dalam pembelajaran menyimak cerita drama telah berhasil atau mampu meningkatkan ketuntasan belajar siswa kelas VIII-A SMP N 2 Sentajo Raya. Ketuntasan yang dicapai mencapai 
$91,67 \%$ dan sudah melewati batas Sentajo Raya.

ketuntasan minimal ketuntasan secara klasikal yaitu 90\% dari keseluruhan siswa.

\section{Pembahasan}

Peningkatan ketuntasan menyimak cerita drama siswa ini dapat dilihat dari pra siklus, siklus I dan siklus II, seperti dalam diagram berikut:

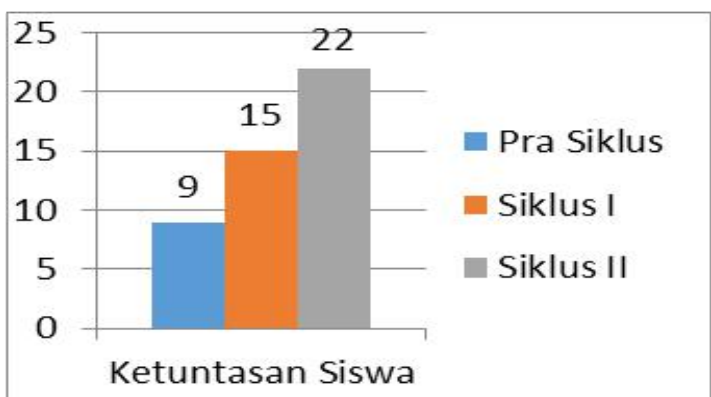

Diagram di atas menggambarkan ketuntasan siswa mulai dari pra siklus, siklus I dan siklus II. Pra siklus siswa yang tidak tuntas berjumlah 15 orang, pada siklus I siswa yang tidak tuntas menurun menjadi 9 orang, tetapi belum mencukupi ketuntasan minimal, maka dilanjutkan pada siklus II, siswa tidak tuntas menurun hanya tinggal 2 orang siswa. Berdasarkan hal tersebut, maka hasil penelitian dapat disimpulkan dengan penerapan PAIKEM dapat meningkatkan hasil Menyimak cerita drama siswa kelas VIII-A SMP N 2

\section{Simpulan dan Saran}

Berdasarkan rumusan masalah dan hasil pembahasan, secara keseluruhan penerapan PAIKEM mampu meningkatkan proses dan hasil pembelajaran menyimak cerita drama siswa kelas VIII-A SMP N 2 Sentajo Raya. Adapun peningkatan proses dan hasil belajar menyimak cerita drama siswa kelas VIII-A. SMP N 2 Sentajo Raya sebagai berikut:

Proses pembelajaran dengan penerapan PAIKEM mengalami peningkatan. Peningkatan tersebut dapat dilihat dari persentase total skor yang di peroleh pada setiap aspek aktivitas guru dan siswa yaitu sebagai berikut. (1) aktivitas guru pada siklus I dengan persentase total skor yang diperoleh yaitu $76,25 \%$ meningkat menjadi $92,5 \%$ pada siklus II. (2) aktivitas siswa pada siklus I dengan persentase total skor yang diperoleh yaitu $79,48 \%$ meningkat menjadi $91,15 \%$ pada siklus II. Data tersebut menunjukkan bahwa telah terjadi peningkatan proses dari segi guru dan 
siswa dalam pembelajaran menyimak

cerita drama.

2. Peningkatan hasil belajar siswa terjadi peningkatan dari siklus I ke siklus II yaitu, siklus I dengan rata-rata $62,5 \%$ dan meningkat pada siklus II dengan rata-rata $91,67 \%$.

\section{Daftar Pustaka}

Antarika, W. 2016. PENERAPAN MODEL ROLE PLAYING Wenti Antarika. Universitas Lampung.

Fatmah, N., \& Jumadi, O. (2016). Pengaruh Strategi PAIKEM ( Pembelajaran Aktif, Inovatif , Kreatif , Efektif , Menyenangkan ) Terhadap Motivasi Dan Hasil Belajar Siswa Influence of PAIKEM Strategy ( Active, Innovative, Creative , Effective , Fun Learning ) On Student Motivation and Student Result, (1), 59-64.

Hartono. 2012. PAIKEM "Pembelajaran Aktif Inovatif Kreatif Efektif dan Menyenagkan." Jogjakarta: Zanafa Publising.

Siregar, Pariang Sonang, \& Wardani Lia, R. G. H. 2017. Penerapan Pendekatan Pembelajaran Aktif Inovatif Pembelajaran Matematika Kelas IV SD Negeri 010 Rambah. Jurnal Pemikiran Dan Pengembangan SD, 5 (September), 743-749.

Slameto. 1991. Belajar dan Faktor-faktor yang Mempengaruhinya. Jakarta: Rineka Cipta. 